Acta vet. scand. $1973,14,176-183$.

From the Department of Microbiology and Immunology, Veterinary College of Norway, Oslo.

\title{
COMPARISON OF BACILLUS THURINGIENSIS WITH OTHER BACILLUS SPECIES BASED ON ENZYMOSEROLOGICAL EXAMINATIONS OF THEIR PROTEOLYTIC ENZYMES
}

\author{
By \\ Olav Sandvik
}

\begin{abstract}
SANDVIK, OLAV: Comparison of Bacillus thuringiensis with other Bacillus species based on enzymoserological examinations of their proteolytic enzymes. Acta vet. scand. 1973, 14, 176-183. - Investigated strains of Bacillus thuringiensis were all good producers of casein precipitating proteinases (CP-enzymes).

CP-enzymes produced by five strains of $B$. thuringiensis were serologically compared with enzymes produced by strains of $B$. cereus, B. licheniformis and B. subtilis. The technique used is a special enzymoserological procedure by which the proteolytic activity is neutralized by specific antisera. A close enzymoserological relationship was demonstrated between $B$. thuringiensis and $B$. cereus, while no interspecies cross-reactions occurred between enzymes of these species, and those of B. licheniformis and B. subtilis.

The possibility of undetected transference of $B$. thuringiensis from bacteriologically treated plant material to animals is discussed in relation to the high degree of similarity between $B$. cereus and $B$. thuringiensis.
\end{abstract}

Bacillus thuringiensis; Bacillus cereus; Bacillus licheniformis; Bacillus subtilis; enzymoserological examination; proteolytic enzymes.

Bacillus thuringiensis (Berliner 1915) and Bacillus cereus (Frankland \& Frankland 1887) are, in the 7th edition of Bergey's Manual of Determinative Bacteriology (Breed et al. 1957), listed as two different species. Apart from the crystalliferous nature of B. thuringiensis (typical strains at the time of sporulation form 
inclusion bodies consisting of parasporal protein crystals (Steinhaus \& Jerrel 1954, Lecadet \& Dedonder 1971)) the cultural, morphological and biochemical properties of the two species seem to correspond so closely that a separation at the level of species is taxonomically debatable. However, B. thuringiensis is maintained in the Manual as a species because of its pathogenicity for certain insects.

B. thuringiensis is of particular interest due to the possibilities of using the organism in agriculture as a biological insecticide (Krieg 1961, 1967; Martignoni 1964). As the insecticidal properties of the organism seem to be connected with only small taxonomical deviations as compared with the classical B. cereus, it is important to be able to characterize the organism as precisely as possible.

More comprehensive studies have been undertaken in recent years in order to determine the position of $B$. thuringiensis in the taxonomical system. As discussed by Krieg (1968), both morphological, serological and biochemical methods and phage typing have been applied. The organism may be divided into serotypes (varieties) that are different from the serotypes of B. cereus, mainly on the basis of flagellar antigens. Other criteria seem to be of less significance as far as the separation of the two taxa is concerned. It has been pointed out (Hannay 1967) that in addition to crystalliferous strains of $B$. thuringiensis, unstable forms that have lost their crystalliferous properties also occur. This statement further weakens the arguments for retaining $B$. thuringiensis as a separate species.

The taxonomy of $\mathrm{B}$. thuringiensis is of particular interest not only in the characterization of the organism as a means in biological control of insects, but its identification is also of importance in order to consider the organism in relation to animal pathogenic strains of $B$. cereus. Thus, B. cereus is of considerable interest in veterinary medicine as a potential cause of rather serious infections and food intoxications.

In the present work, the Bacillus species mentioned, and related organisms, have been studied by serological analyses of their extracellular proteolytic enzymes. The method used (Sandvik 1962, 1969) is an immunoclectrophoretic procedure by which the specific antiproteinases are separated by paper electrophoresis from the normally occurring and interfering proteinase inhibitors in the sera of immunized rabbits. The antiproteolytic effect of 
the specific antibodies is demonstrated by their ability to inhibit the corresponding enzymes from precipitating sodium caseinate in an agar medium. Many serologically different proteolytic enzymes were demonstrated in material from various species. The enzymes studied have been shown to be specific for well defined groups of organisms, and cross-reactions between species and genera have only been observed in a few cases where a more, or less, close relationship is probable between the organisms in question. Thus, the antigenicity of these enzymes seems to be of considerable taxonomic significance. As the antigens used in this method are determined by their functional enzymatic properties, it is possible to idcntify the proteinases and the corresponding organisms without purifying the enzymes.

Enzymoserological analyses, as mentioned above, are presumed to be of major importance in considering the relationships in question.

\section{MATERIALS AND METHODS}

Strains. A total of 13 Bacillus strains (Table 1) was used in this study. The strains were obtained from the American Type Culture Collection, Rockville, Maryland, USA (ATCC), the National Collection of Industrial Bacteria, Torry Research Station, Aberdeen, Scotland (NCIB) or the Culture Collection at the Department of Microbiology and Immunology, Veterinary College of Norway, Oslo (NVH). The identity of the cultures was rechecked on the basis of conventional cultural and physiological criteria.

Enzymes. The Bacillus proteinases were produced by growing the organisms in semi-solid skim milk agar (nutrient broth, $40 \%$; nutrient agar, $42 \%$; autoclaved skim milk, $18 \%$ ) in Roux bottles for 3-5 days at $37^{\circ} \mathrm{C}$. Enzymes to be used for developing the immuno-electrophoretic patterns (see below) were usually produced in peptone water (Peptone, $1 \% ; \mathrm{NaCl}, 0.5 \%$ ). The harvesting of cultures, and the concentration and purification procedure have been described (Sandvik 1962).

Sera. Specific antiproteinases were produced in rabbits as described by Sandvik (1969). Four different antisera were used (Table 1).

Caseinate medium. The indicator medium used to test for proteinase activity was prepared as follows: Agar (Difco, Bactoagar 0140-01), $1.4 \%$; sodium caseinate (Eastman Kodak, added 


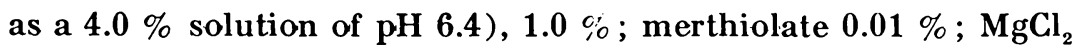
(added as a $10.0 \%$ solution), $0.004 \mathrm{M}$; in distilled water. The medium was mixed and poured while hot, and remained transparent even after incubation at $37^{\circ} \mathrm{C}$, while the so-called CP-type (Casein Precipitating type) of proteolytic enzymes caused distinct greyish-white precipitation zones in the medium on incubation.

Enzymoserological differentiation. 'The so-called electrophoretic Casein Precipitating Inhibition test (CPI-test) (Fossum 1970) - was used for the separation of the antiproteinases and the naturally occurring proteinase inhibitors in the immune sera (Sandvik 1962). By this procedure, the natural inhibitors are localized in the $\alpha$-and $\beta$-globulins, on the anode side of the line of application, while the inhibition due to induced antibodies occurs in the region of the $\gamma$-globulins. After transferring the serum electrophorogram from the paper electrophoresis strips to caseinate agar plates, followed by "developing" the medium with filter paper strips soaked in the enzyme solutions to be tested, zones of inhibition of the enzyme-produced precipitation occur where inhibitors, or antiproteinases, are localized (Fig. 1). Under the present conditions, the $\gamma$-globulins are situated on both sides of the line of application. The width of the inhibition zones will depend on the concentration of enzyme antibodies, or other inhibitors, and the strength of the enzyme solution used for developing.

\section{RESULTS}

All the strains used in the study produced large amounts of extracellular proteinases, which caused white zones of precipitation when applied into the caseinate medium. The antienzymes revealed typical, specific zones of inhibition in the enzymoserological test when developed with the homologous enzyme solutions.

All the Bacillus strains were cross-tested against the antienzymes included in Table 1 . It can be seen from Table 1 that all strains of $B$. thuringiensis react with $B$. cereus (NVH 322) antienzyme. B. cereus proteinases also cross-react with $B$. thuringiensis antienzyme. However, as pointed out in the table different types of serological reactions were observed. Thus, two serologically different enzymes occurred after developing B. cereus or $B$. thuringiensis antienzymes with enzymes produced by B. thuringiensis, strain ATCC 13367. One of the enzymes (de- 
Table 1. Proteinases produced by different strains, tested with various antiproteinases.

Proteinases produced in peptone water by
Reaction when testing the proteinases with antienzymes against

\begin{tabular}{|c|c|}
\hline B. thuringiensis & B. cereus \\
\hline
\end{tabular}
ATCC 10792
NVH 322

\section{NCIB 8057} NCIB 1955
B. thuringiensis ATCC 10792
B. thuringiensis ATCC 13366
B. thuringiensis ATCC 13367
B. thuringiensis (com) *
B. cereus NVH 322
B. cereus ATCC 14579
B. cereus NVH 132
B. subtilis NCIB 8057
B. subtilis ATCC 6051
B. licheniformis NCIB 1955
B. licheniformis ATCC 14580

$+++:$ Inhibitory effect equal to homologous reaction.

* A and B designate two different casein precipitating enzymes.

* A strain isolated from a commercial product used in biological insect control.

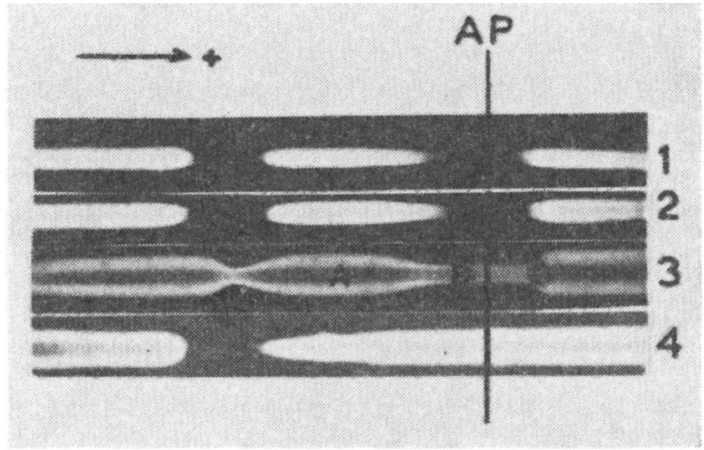

Figu r e 1. Electrophoretic patterns for antiserum against the casein precipitating enzyme of $\mathrm{B}$. cereus (NVH 322) transferred to caseinate agar. Developments were performed with enzymes produced by 1) B. cereus (ATCC 14579), 2) B. thuringiensis (ATCC 10792), 3) B. thuringiensis (ATCC 13367) and 4) B. licheniformis (ATCC 14580). The specific antiproteinases are localized in the area of the line of application (AP) and the normally occurring serum inhibitors to the left of this line. The enzymoserological reactions are: homologous type of reaction ( 1 and 2), one enzyme of two being inhibited (3) and no specific reaction (4).

The electrophoresis was carried out in $0.05 \mathrm{M}$ phosphate buffer at $\mathrm{pH} 6.2$, for $18 \mathrm{hrs}$. at $120 \mathrm{v}$. 
signated A-type) revealed a wide zone of inhibition, while the other (B-type) was not inhibited at all. As the A-type was present at a higher concentration than the B-type, the latter caused a narrow uninterrupted precipitation bridge within the inhibition area of enzyme A (Fig. 1).

No reaction occurred between $B$. thuringiensis or $B$. cereus on one side and B. subtilis or B. licheniformis antienzymes on the other.

\section{DISCUSSION}

Like B. cereus, B. thuringiensis produces large amounts of so-called casein precipitating enzymes (CP-enzymes). The tests presented in Table 1 indicate identity, or close serological relationship, between the proteolytic enzymes of $B$. thuringiensis and $B$. cereus, while the representatives of these species are distinctly enzymoserologically different from B. subtilis and B. licheniformis.

The phenomenon that the ATCC 13367 strain of B. thuringiensis seems to produce at least two serologically different enzyme fractions, only one of which (the A-fraction) is inhibited, indicates that the $B$. thuringiensis and $B$. cereus antienzymes behave in a similar fashion to that which was demonstrated for species of the genera Aeromonas (Sandvik \& Hagen 1968) and Vibrio (Sandvik \& Dahle 1971). In the present study, strain B. thuringiensis ATCC 13367 is different from the other strains of B. thuringiensis and B. cereus tested, in that it produces a proteinase fraction (the B-fraction) that could not be found in any of the other strains. In this connection, it should be emphasized that proteolytic bacteria which produce complexes of different proteinases may show different enzyme patterns when grown in different media (Dahle 1969). Preliminary assays carried out with strains cultivated in litmus milk rather than peptone water (Sandvik unpublished) revealed a more complex proteinase pattern for some of the $B$. thuringiensis and $B$. cereus strains, with additional fractions which could not be demonstrated in peptone water cultures. Thus, enzymoserological comparisons of this kind should be carried out with enzymes formed in the same type of medium.

In conclusion, enzymoserological analyses indicate a very close relationship between $B$. thuringiensis and B. cereus, supporting the view that these organisms should be considered 
varieties within the same species. Hence, the possibility of undetected transference of organisms from $B$. thuringiensis treated plant material should be kept in mind when B. cereus is isolated from animal species.

\section{REFERENGES}

Berliner, E.: Úber die Schlafsucht der Mehlmottenraupe (Ephestia kühniella, Zell.) und ihren Erreger Bacillus thuringiensis, n.sp. (A disease in the larvae of the flour moth (Ephestia kühniella, Zell.) and the causative agent Bacillus thuringiensis, n.sp.). Z. angew. Entomol. 1915, 2, 29-56.

Breed, R. S., E. G. D. Murray \& N. R. Smith: Bergey's Manual of Determinative Bacteriology. 7th Ed. The Williams \& Wilkins Co., Baltimore, Maryland 1957.

Dahle, H. K.: Enzymoserological separation of bacterial proteinases. Acta path. microbiol. scand. 1969, 77, 143-148.

Fossum, K.: Proteolytic enzymes and biological inhibitors. III. Naturally occurring inhibitors in sera from different species and their effect upon proteolytic enzymes of various origin. Acta path. microbiol. scand. Section B. 197.0, 78, 605-618.

Frankland, Grace C. \& P. F. Frankland: Studies on some new microorganisms obtained from air. Phil. Trans. 1887, 187, 257-287.

Hannay, C. L.: The dissociation of Bacillus thuringiensis. Canad. J. Microbiol. 1967, 13, 1566-1568.

Krieg, A.: Bacillus thuringiensis Berliner. ther seine Biologie, Pathogenie und Anwendung. (Bacillus thuringiensis Berliner. The biology, pathogenicity and application). Mitt. biol. BundAnst. Ld- u. Forstw. 1961, 103, 1-79.

Krieg, A.: Neues über Bacillus thuringiensis und seine Anwendung. (More about Bacillus thuringiensis and the application of the organism). Mitt. biol. BundAnst. Ld- u. Forstw. 1967, 125, 1-106.

Krieg, A.: A taxonomic study of Bacillus thuringiensis Berliner. J. invertebr. Path. 1968, 12, 366-378.

Lecadet, Marguerite-M. \& R. Dedonder: Biogenesis of the crystalline inclusion of Bacillus thuringiensis during sporulation. Europ. J. Biochem. 1971, 23, 282-294.

Martignoni, M. E.: Mass production of insect pathogens. In Biological Control of Insect Pests and Weeds. ed. Paul DeBach, assisted by Evert I. Schlinger, Chapman and Hall Ltd. London 1964, $579-609$.

Sandvik, O.: Studies on casein precipitating enzymes of aerobic and facultatively anaerobic bacteria. The Veterinary College of Norway, Oslo 1962, 116 pp.

Sandvik, O.: Enzymo-serological comparison of proteolytic enzymes produced by Salmonella species and other enterobacteria. Acta vet. scand. $1969,10,225-233$. 
Sandvik, O. \& O. Hagen: Serological studies on proteinases produced by Aeromonas salmonicida and other aeromonads. Acta vet. scand. $1968,9,1-9$.

Sandvik, O. \& H. K. Dahle: Enzymoserological relationship between Vibrio comma and other Gram-negative organisms. Acta path. microbiol. scand. Section B. 1971, 79, 285-290.

Steinhaus, E. A.\& Elizabeth A. Jerrel: Further observations on Bacillus thuringiensis Berliner and other sporeforming bacteria. Hilgardia $1954,23,1-21$.

\section{SAMMENDRAG}

Sammenligning av Bacillus thuringiensis med andre Bacillus-arter basert på enzymoserologiske unders $\phi k e l s e r$ av deres proteolytiske enzymer.

Alle unders $\varnothing$ kte stammer av Bacillus thuringiensis var gode produsenter av kaseinpresipiterende proteinaser (CP-enzymer).

CP-enzymer produsert av fire stammer av B. thuringiensis ble sammenlignet serologisk med enzymer produsert av B. cereus, B. licheniformis og B. subtilis. Den anvendte teknikk er en spesiell enzymoserologisk metode hvorved den proteolytiske aktivitet blir nøytralisert av spesifikke antisera. Det ble funnet et nært enzymoserologisk slektskap mellom B. thuringiensis og B. cereus, mens det ikke ble påvist kryssreaksjoner mellom enzymer fra disse arter på den ene side og enzymer fra B. licheniformis og B. subtilis på den annen.

Muligheten for uoppklart overf $\varnothing$ ring av B. thuringiensis fra bakteriebehandlet plantemateriale til dyr er diskutert ut fra den høye grad av likhet som eksisterer mellom B. cereus og B. thuringiensis.

(Received November 16, 1972).

Reprints may be requested from: Olav Sandvik, Department of Microbiology and Immunology, Veterinary College of Norway, Postbox 8146, Oslo Dep., Oslo 1, Norway. 